\title{
Quality and seasonal variation of rainwater harvested from concrete, asphalt, ceramic tile and green roofs in Chongqing, China
}

\author{
Qianqian Zhang ${ }^{\mathrm{a}, \mathrm{b}}$, Xiaoke Wang ${ }^{\mathrm{a}, *}$, Peiqiang Hou ${ }^{\mathrm{a}}$, Wuxing Wan ${ }^{\mathrm{a}, \mathrm{c}}$, Ruida Li $^{\mathrm{a}}$, \\ Yufen Ren ${ }^{a}$, Zhiyun Ouyang ${ }^{a}$ \\ a State Key Laboratory of Urban and Regional Ecology, Research Center for Eco-Environmental Sciences, Chinese Academy of Sciences, Beijing 100085, China \\ ${ }^{\mathrm{b}}$ Institute of Hydrogeology and Environmental Geology, Chinese Academy of Geological Science, Shijiazhuang 050061, China

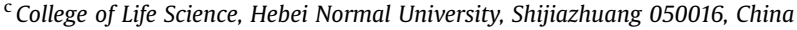

\section{A R T I C L E I N F O}

\section{Article history:}

Received 23 March 2013

Received in revised form

12 August 2013

Accepted 3 November 2013

Available online 6 December 2013

\section{Keywords:}

Roofing material

Seasonal variation

Water quality

Roof management

Rainwater harvesting

\begin{abstract}
A B S T R A C T
There is an urgent requirement to examine the quality of harvested rainwater for potable and nonpotable purposes, based on the type of roofing material. In this study, we examined the effect on the quality of harvested rainwater of conventional roofing materials (concrete, asphalt and ceramic tile roofs) compared with alternative roofing materials (green roof). The results showed that the ceramic tile roof was the most suitable for rainwater-harvesting applications because of the lower concentrations of leachable pollutants. However, in this study, the green roof was not suitable for rainwater harvesting applications. In addition, seasonal trends in water quality parameters showed that pollutants in roof runoff in summer and autumn were lower than those in winter and spring. This study revealed that the quality of harvested rainwater was significantly affected by the roofing material; therefore, local government and urban planners should develop stricter testing programs and produce more weathering resistant roofing materials to allow the harvesting of rainwater for domestic and public uses.
\end{abstract}

(c) 2013 Elsevier Ltd. All rights reserved.

\section{Introduction}

In recent years, fresh water availability has become one of the main issues facing humankind (Vialle et al., 2012). With rapid urbanization, industrialization and population growth, drinking water availability has decreased. Since the reformation and openingup of China, water resource problems related to environmental degradation have become increasingly serious due to rapid industrialization and urbanization. Although many solutions have been proposed, there is much interest in the use of roof-collected rainwater. Rainwater harvesting ( $\mathrm{RWH})$ in urban areas is a strategy that brings many benefits and could provide solutions to address current water shortages, urban stream degradation and flooding (Fletcher et al., 2008; Van Roon, 2007).

Rainwater is usually the cleanest available water source (Gonçalves et al., 2003) and RWH is one of the best methods available for establishing sustainable water cycles in urban developments (Lye, 2009). Roofs are the first candidates for RWH systems because their runoff is often regarded as unpolluted (Förster, 1999). However, some studies have reported that there is a

\footnotetext{
* Corresponding author. Tel./fax: +86 1062943822

E-mail address: wangxk@rcees.ac.cn (X. Wang).
}

potential for rainwater to carry nutrient pollution (total phosphorus and nitrate nitrogen) (Vijayaraghavan et al., 2012), microbial pathogens (Ahmed et al., 2008; Simmons et al., 2001), heavy metals (Lee et al., 2010; Wang and Li, 2009) and pesticides (Zobrist et al., 2000). Therefore, it is essential to investigate the water quality of roof runoff for domestic use.

The quality of harvested rainwater has also been found to be dependent both on the roof type and environmental conditions (local climate and the level of atmospheric pollution) (Lee et al., 2010). Chang et al. (2004) compared harvested rainwater quality from four roof types (wood shingle, composition shingle, painted aluminum, and galvanized iron) at Nacogdoches, Texas. They found that the $\mathrm{pH}$, electrical conductivity (EC), and zinc levels were significantly influenced by the type of roofing material, and the runoff quality from wood shingles was the worst of the four roof types studied. Despins et al. (2009) found that the quality of harvested rainwater from steel roofs was better than that from asphalt shingle roofs, particularly with respect to total organic carbon, turbidity and color. Mendez et al. (2011) examined harvested rainwater quality from five roof types (conventional roofing materials: asphalt fiberglass shingle, Galvalume metal, and concrete tile; alternative roofing materials: cool and green) at Austin, Texas. They found that the metal, concrete tiles and cool roofs were suitable for rainwater harvesting application; however, the shingle 
and green roofs produced very high dissolved organic carbon concentrations, which could lead to high concentrations of disinfection byproducts. Lee et al. (2012) compared harvested rainwater quality from four roof types (wooden shingles, concrete tiles, clay tiles $[G i-W a]$ and galvanized steel) at Seoul, South Korea. They found that galvanized steel was the most suitable for rainwater harvesting applications after the first flush, followed by clay tiles.

Most studies to date have focused on examining roofing materials, such as galvanized metal, galvanized iron and wooden shingles for rainwater harvesting. However, investigations comparing green roofs with conventional roofs (concrete, asphalt and ceramic tiles) have rarely been reported. In China, the conventional roof mainly consists of concrete, asphalt and ceramic tiles, with green roofs increasingly being installed for their stormwater retention characteristics. Therefore, it is important to investigate harvested rainwater quality from the four roof types (concrete, asphalt, ceramic tiles and green roofs) in order to select the best type for RWH.

In China, there is a long history of using rainwater from roofs for drinking or household use. Unfortunately, in recent years, rainwater from roofs has been harvested less because of concerns over rainwater quality. Although roof rainwater has been monitored in some cities, such as Beijing (Ren et al., 2008), Shanghai (Wang and Li, 2009), and Macau (Huang et al., 2006), the difference in rainwater quality from different roofing material has not been assessed. In this study, rainwater from concrete, asphalt, ceramic tiles and green roofs will be monitored in ambient conditions, with the aim to provide more information for encouraging rainwater harvesting strategies and technologies.

The main objective of our study was to thoroughly examine the effect of roofing material on the quality of harvested rainwater for domestic use. The specific objectives were to: 1) assess the differences in water quality between different roofs; 2 ) determine the degree of association between water quality parameters and storm characteristics, as well as the association between the water quality parameters themselves; and 3) analyze the seasonal variation of water quality on different roofing materials.

\section{Materials and methods}

\subsection{Study site}

The roof rainwater runoff was monitored in Yubei district, Chongqing, China. The site was a new development zone surrounded by a school, road and building land. The area has a subtropical monsoon climate with a mean annual temperature of 17.5$18.7^{\circ} \mathrm{C}$, and a mean annual precipitation of $1100-1300 \mathrm{~mm}$. The 12 months can be divided into 4 seasons (spring [March to May], summer [June to August], autumn [September to November], and winter [December, January and February]). Most of the precipitation occurs between April and July (Fig. 1), and the highest temperature occurs between July and September.

\subsection{The roof structure}

The conventional pilot-scale roofs made from different materials (concrete, asphalt and ceramic tiles were $1.5 \times 1.5 \mathrm{~m}$, and the "green" (vegetated) roof was $1.0 \times 1.0 \mathrm{~m}$ ) were laid in parallel on the roof of a middle school. The pilot-scale roofs were positioned $1 \mathrm{~m}$ above the school building roof, and had a $40 \mathrm{~cm}$ fence with potable-quality polyvinyl chloride (PVC) lining to prevent rainwater splashing off the roof (Fig. 2). Each roof was installed in accordance with local construction material standards and the two duplicate pilot-scale roofs were arranged in an alternating sequence. Thus, there were eight roofs in this study, consisting of two of each of the four roof types. The ceramic tile roof had a high

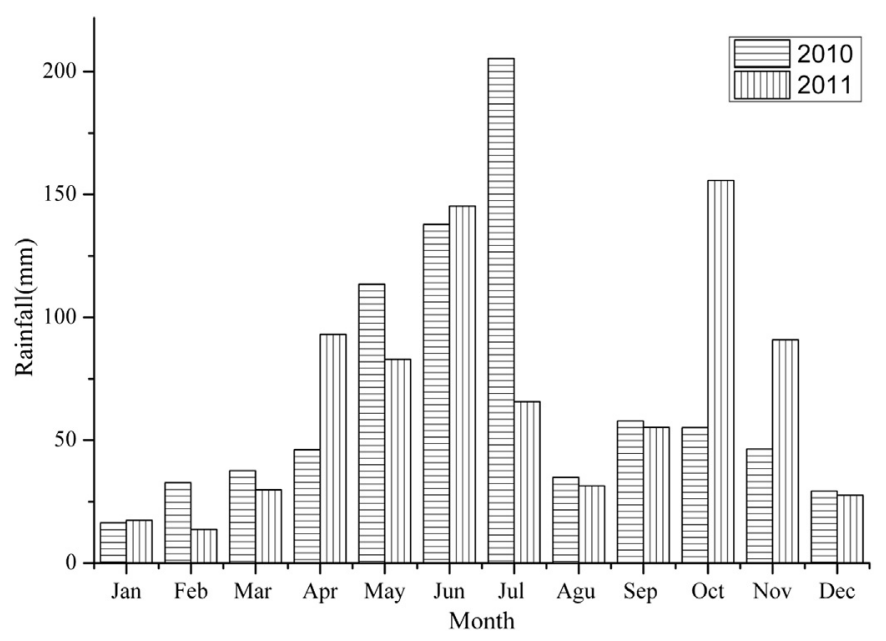

Fig. 1. Temporal variations of rainfall for 2010-2011.

slope angle $\left(25^{\circ}\right)$ and smooth surface, whereas the concrete and green roofs were flat and had rough surfaces. The asphalt roof had a flat and smooth surface.

The green roof assembly consisted of four layers (Fig. 3), the uppermost being a vegetation layer comprised of a thick growing substrate $(15 \mathrm{~cm})$ and plants. The second layer was a filter layer in the form of a non-woven geotextile, which prevented small particles from being washed from the substrate layer into the drainage layer or out of the system. The third layer was a drainage layer in the form of a large plastic plate (length $\times$ width $\times$ height: $33.3 \times 33.3 \times 2.0 \mathrm{~cm}$ ). The last layer was an additional waterproof layer comprising modified asphalt felt paved onto the original concrete roof.

The substrate was a commercial product manufactured using a mixture of lightweight materials (the volume ratio of each matrix: peat soil:vermiculite:perlite:sawdust was 4:3:2:1).

The selection of plant species was based on their ability to survive in conditions of low nutrients, drought and extreme temperature. Buddhanail (Sedum lineare Thunb) was selected for the present study, and was planted in the substrate at a density of 162 plugs $/ \mathrm{m}^{2}$ (plant spacing is $4-6 \mathrm{~cm}$ and line spacing $8-10 \mathrm{~cm}$ ).

\subsection{Rainwater sampling devices}

A sampling insert ( $6 \mathrm{~cm}$ internal diameter potable quality PVC pipe) was placed in the gutters of the pilot-scale roof and at the PVC pipe outlet connected to a plastic pipe (100 cm long), which was in turn connected to a plastic pipe sampler (the sampler material was polyethylene) (Fig. 2).

\subsection{Sampling and analyses}

\subsubsection{Sample collection}

Rainwater harvested from the pilot-scale roofs (except the green roof) was sampled for 47 rain events from August 2010 to November 2011, and the green roof was sampled for 12 rain events from May to November 2011. The sampling was performed using a plastic cup. Prior to sampling, the plastic cup was rinsed three times with pure water and twice with the uniformly mixed roof runoff harvested in the sampler. Subsequently, three water samples were collected from each roof and were stored in $1 \mathrm{~L}$ polyethylene bottles in an ice bag filled contains and immediately transported to the laboratory. During the rainwater sampling, the diversion of first flush was not applied. During our study, the precipitation ranged 


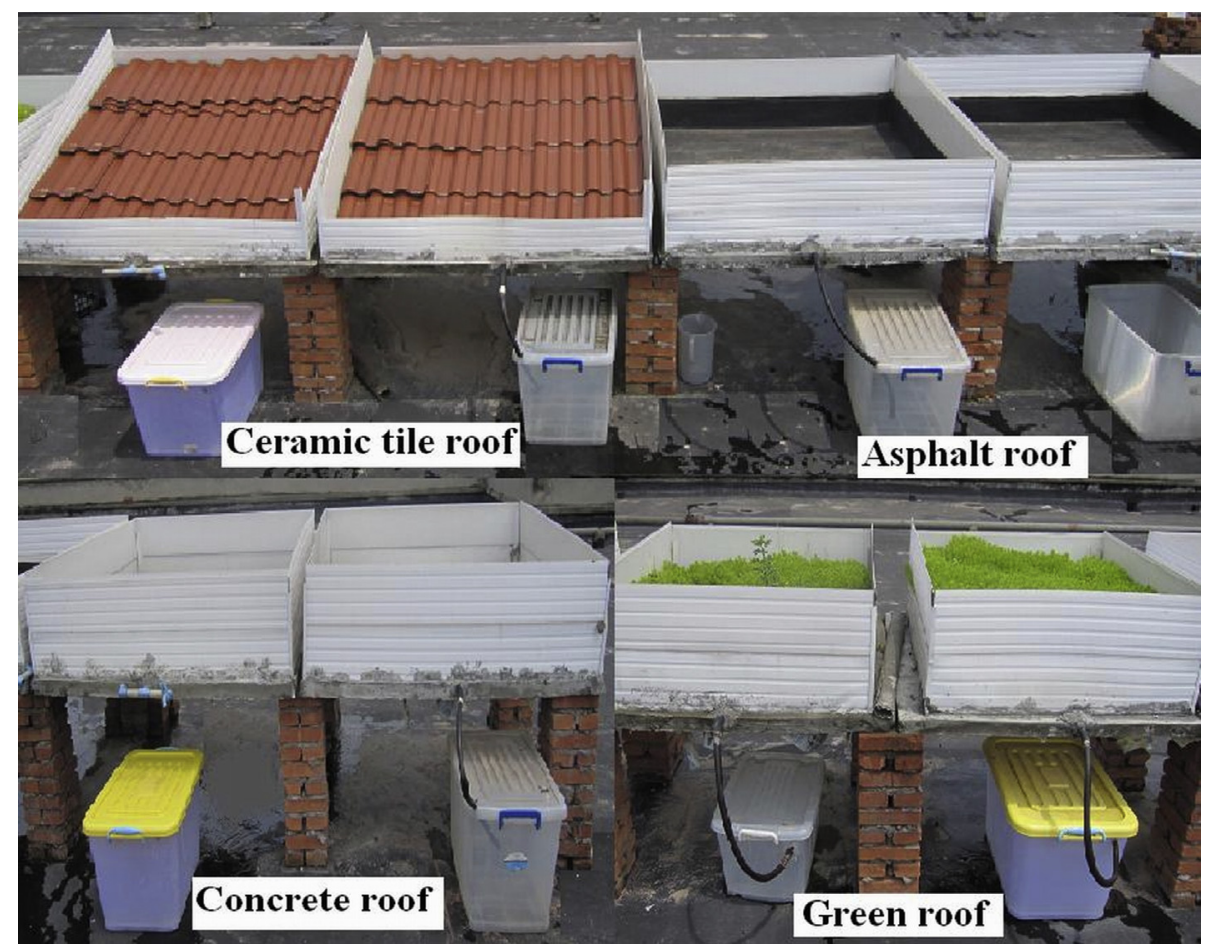

Fig. 2. Conventional roofs (concrete, asphalt and ceramic tile roofs) and the green roof.

from 1 to $84.8 \mathrm{~mm}$, and the antecedent dry weather period (ADWP) ranged from $3 \mathrm{~h}$ to 33.9 days for all roofs.

\subsubsection{Physical-chemical analysis}

After the composite sample was obtained, the rainwater sampler was emptied and samples were immediately prepared for analyses. The $\mathrm{pH}$ and EC were analyzed using a portable meter (Hach, USA, Sension $\left.{ }^{\mathrm{TM}} 156\right)$. In accordance with the National Standard Method of China (GB3838-2002a), chemical oxygen demand (COD) was analyzed using the rapid digestion and spectrophotometric method; total nitrogen (TN) was measured using the alkaline potassium persulfate digestion and UV spectrophotometric method; total phosphorus (TP) was measured using the persulfate digestion and spectrophotometric method; total suspended solids (TSS) were measured using the filtering, drying and weighing method; total organic carbon (TOC) was measured using a total carbon analyzer (Elementar, German, Liquid TOCII); cations (potassium $\left[\mathrm{K}^{+}\right]$, sodium $\left[\mathrm{Na}^{+}\right]$, calcium $\left[\mathrm{Ca}^{2+}\right]$, magnesium $\left[\mathrm{Mg}^{2+}\right]$ and silicate $\left[\mathrm{Si}^{4+}\right]$ ) were measured using an inductively coupled plasma optical emission spectrometer (ICP-OES) (Leemans, USA, Prodigy); and anions (fluoride $\left[\mathrm{F}^{-}\right]$, chloride $\left[\mathrm{Cl}^{-}\right]$and sulfate $\left[\mathrm{SO}_{4}^{2-}\right]$ ) were

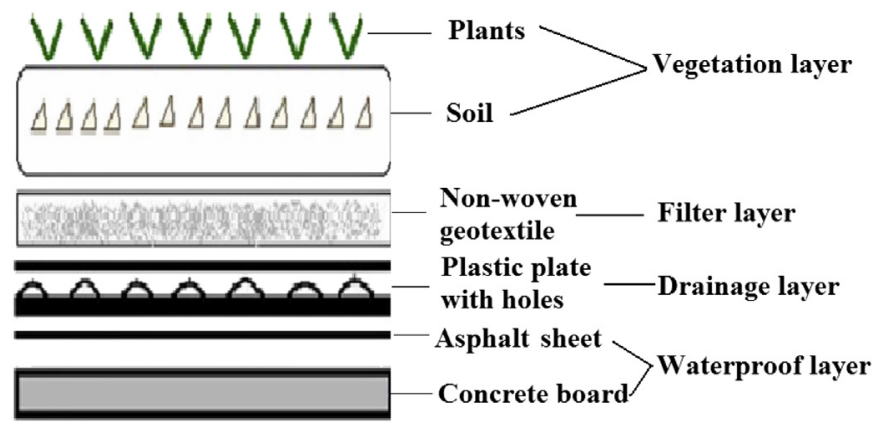

Fig. 3. Cross-sectional structure of the green roofs used in this experiment. measured using an ion chromatograph (Dionex, USA, ICS-1000). The major dissolved metals (copper and zinc) were analyzed using an inductively coupled plasma mass spectrometer (Agilent Technologies USA, ICP-MS 7500a).

The quality assurance and quality control (QA/QC) for water sampling and analysis strictly followed the guidelines set by SEPAC (2002a).

\subsubsection{Multivariate data analysis}

Differences in water quality from the different roofing materials were evaluated using the nonparametric Kruskall-Wallis test because the data deviated from a normal distribution that did not allow for the application of parametric statistical analysis. The Mann-Whitney $U$ test was used to compare the two groups when the Kruskall-Wallis test found the overall difference to be significant $(P<0.05)$. The same nonparametric tests were applied to assess the seasonal variation of rainwater quality for each roofing material, except the green roof where only 12 rain events were sampled which did not cover all seasons of a year. Correlation analysis was used to determine the degree of association between water quality parameters and storm characteristics such as rainfall volume, ADWPs, last rainfall volume and maximum rainfall intensity. Again, the Spearman's rank correlation coefficient was used because the data failed to meet the assumptions for calculating parametric Pearson's correlation coefficient.

Statistical tests were performed using SPSS 19.0 (SPSS Inc., USA).

\section{Results}

\subsection{Quality assessment}

\subsection{1. $p H, E C$ and TSS}

The mean $\mathrm{pH}, \mathrm{EC}$ and TSS concentration showed significant differences among the four types of roofs (Fig. 4). The mean pH and TSS from the concrete roof $(7.58$ and $120 \mathrm{mg} / \mathrm{L})$ were significantly higher than others, while the mean EC value from the green roof 
( $225 \mu \mathrm{S} / \mathrm{cm}$ ) was significantly higher than the others. The $\mathrm{pH}$ of the rainwater harvested from the four types of roofs met the drinking water standard range of 6.0-9.0 (SEPAC, 2002b).

\subsubsection{Nutrients and organic related parameters}

The average TP concentrations from all of the pilot-scale roofs exhibited no significant differences (Fig. 5A). The average TN, TOC and COD concentrations from the green roof $(18.3 \mathrm{mg} / \mathrm{L}, 60.3 \mathrm{mg} / \mathrm{L}$ and $231 \mathrm{mg} / \mathrm{L}$ ) were significantly higher than those of the three other roofing material (Fig. 5). The TN and TOC of the asphalt roof were significantly higher than those of the concrete and ceramic tile roofs. The average TN and COD concentrations of the rainwater harvested for all pilot-scale roofs exceeded the drinking water standards of $1.0 \mathrm{mg} / \mathrm{L}$ and $20.0 \mathrm{mg} / \mathrm{L}$ (SEPAC, 2002b), respectively. According to the national drinking water standards (SEPAC, 2002b), the percentages of exceedance of events of TN, TP and COD concentrations in the rainwater harvested were $100 \%, 31.9 \%$ and $93.6 \%$ for concrete roof, $97.9 \%, 14.9 \%$ and $97.9 \%$ for asphalt roof, $100 \%, 12.8 \%$ and $93.6 \%$ for ceramic tile roof and $100 \%, 0 \%$ and $100 \%$ for green roof, respectively.

\subsubsection{Anions and cations}

The average $\mathrm{Cl}^{-}$and $\mathrm{SO}_{4}^{2-}$ concentrations of the green roof (20.8 $\mathrm{mg} / \mathrm{L}$ and $51.8 \mathrm{mg} / \mathrm{L}$ ) were significantly higher than those of the three other roofing material samples (Fig. 6). The mean $\mathrm{F}^{-}, \mathrm{Cl}^{-}$ and $\mathrm{SO}_{4}^{2-}$ concentration of the rainwater harvested from the four types of roofs met the drinking water standard range of $1.0 \mathrm{mg} / \mathrm{L}$, $250 \mathrm{mg} / \mathrm{L}$ and $250 \mathrm{mg} / \mathrm{L}$ (SEPAC, 2002b), respectively. However, the percentage of events exceeding the national drinking water standard for $\mathrm{F}^{-}$concentration of harvested rainwater was $2.77 \%, 10.64 \%$, $6.38 \%$ and $25 \%$ for the concrete, asphalt, ceramic tile and green roofs, respectively.

The average $\mathrm{K}^{+}, \mathrm{Na}^{+}, \mathrm{Mg}^{2+}$ and $\mathrm{Si}^{4+}$ concentrations of the green roof $(11.3 \mathrm{mg} / \mathrm{L}, 3.29 \mathrm{mg} / \mathrm{L}, 5.17 \mathrm{mg} / \mathrm{L}$ and $17.4 \mathrm{mg} / \mathrm{L}$ ) were significantly higher than those of the three other roofing material samples (Fig. 7). The average $\mathrm{K}^{+}, \mathrm{Na}^{+}$and $\mathrm{Si}^{4+}$ concentrations of the concrete roof were significantly higher than those of both the asphalt and ceramic tile roofs, and the average $\mathrm{Mg}^{2+}$ concentrations of the concrete and ceramic tile roof were significantly higher than that of asphalt roof (Fig. 7). The average $\mathrm{Ca}^{2+}$ concentrations of the green roof $(37.3 \mathrm{mg} / \mathrm{L})$ and concrete roof $(28.6 \mathrm{mg} / \mathrm{L})$ showed no significant difference, however, they were higher than those of the other two roofing material samples: asphalt roof $(18.0 \mathrm{mg} / \mathrm{L})$ and ceramic tile roof (11.2 mg/L) (Fig. 7C).

\subsubsection{Metals}

The average $\mathrm{Cu}(\mathrm{aq})$ concentrations of the green roof $(13.0 \mu \mathrm{g} / \mathrm{L})$ were significantly higher than those of the three other roofing material samples: concrete roof $(5.06 \mu \mathrm{g} / \mathrm{L})$, asphalt roof $(6.79 \mu \mathrm{g} / \mathrm{L})$ and ceramic tile roof $(3.62 \mu \mathrm{g} / \mathrm{L})$ (Fig. 8A). The average $\mathrm{Cu}(\mathrm{aq})$ concentrations of the asphalt roof were significantly higher than the ceramic tile roof. The average $\mathrm{Zn}(\mathrm{aq})$ concentrations of the asphalt roof $(58.3 \mu \mathrm{g} / \mathrm{L})$ were significantly higher than that of concrete roof $(9.72 \mu \mathrm{g} / \mathrm{L})$ and ceramic tile roof $(33.0 \mu \mathrm{g} / \mathrm{L})$ (Fig. $7 \mathrm{~B})$. The mean concentrations of $\mathrm{Cu}(\mathrm{aq})$ and $\mathrm{Zn}(\mathrm{aq})$ in the rainwater harvested from the four roofs met the drinking water standard value of $1000 \mu \mathrm{g} / \mathrm{L}$ and $1000 \mu \mathrm{g} / \mathrm{L}$ (SEPAC, 2002b), respectively.

\subsection{Seasonal characteristics of water quality using different roofing materials}

The seasonal variations of water quality produced from the concrete, asphalt and ceramic tile roofs are shown in Table 1. On the three roofs, the mean $\mathrm{pH}$ concentrations in summer were significantly higher than in winter, while the mean TN concentration in winter was significantly higher than for the other seasons. The lowest TN concentration in summer was from the asphalt and
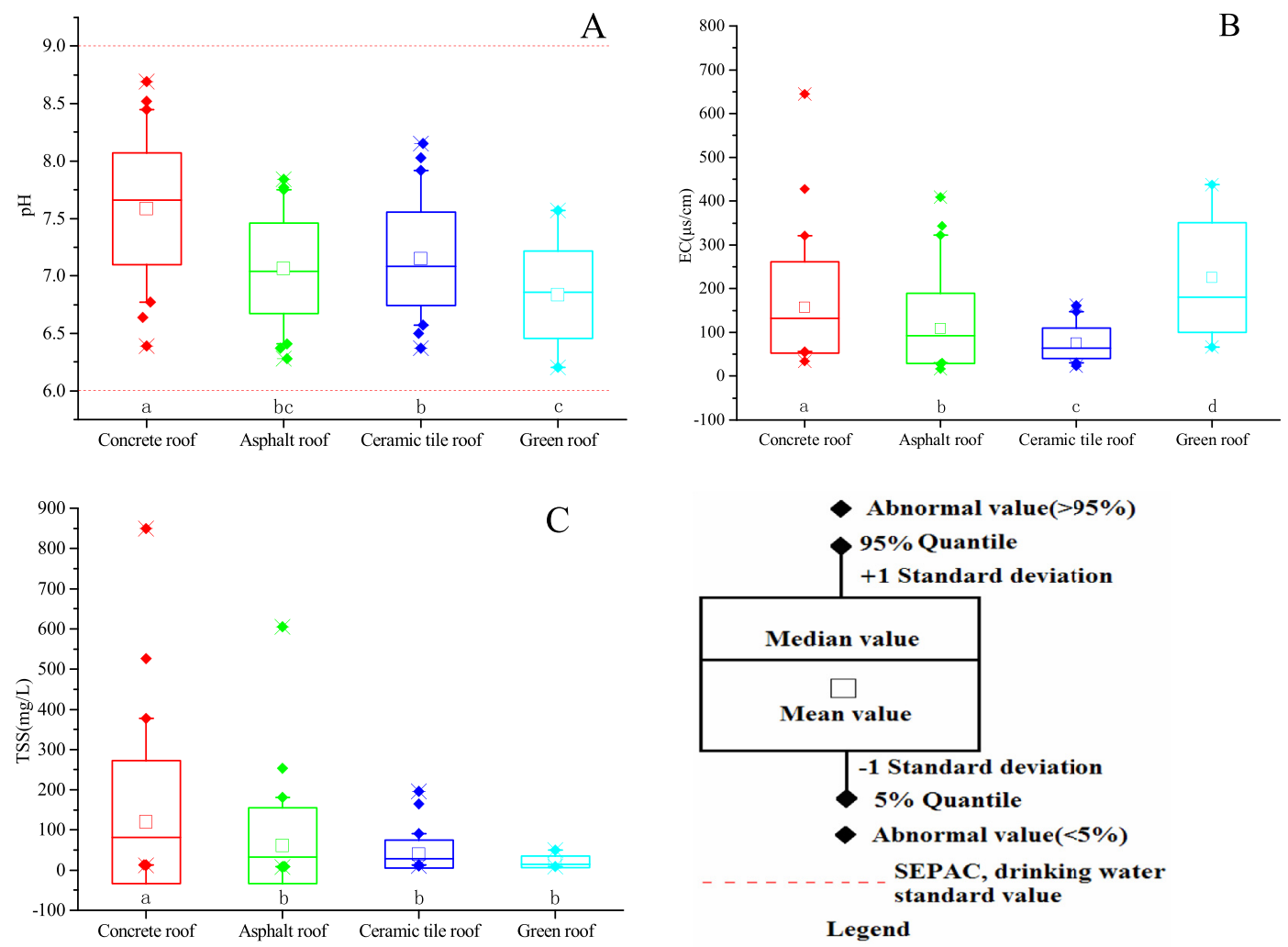

Fig. 4. Box plot diagram showing of the (A) $\mathrm{pH},(B)$ EC and (C) TSS values of rainwater harvested from the four roofing materials. 

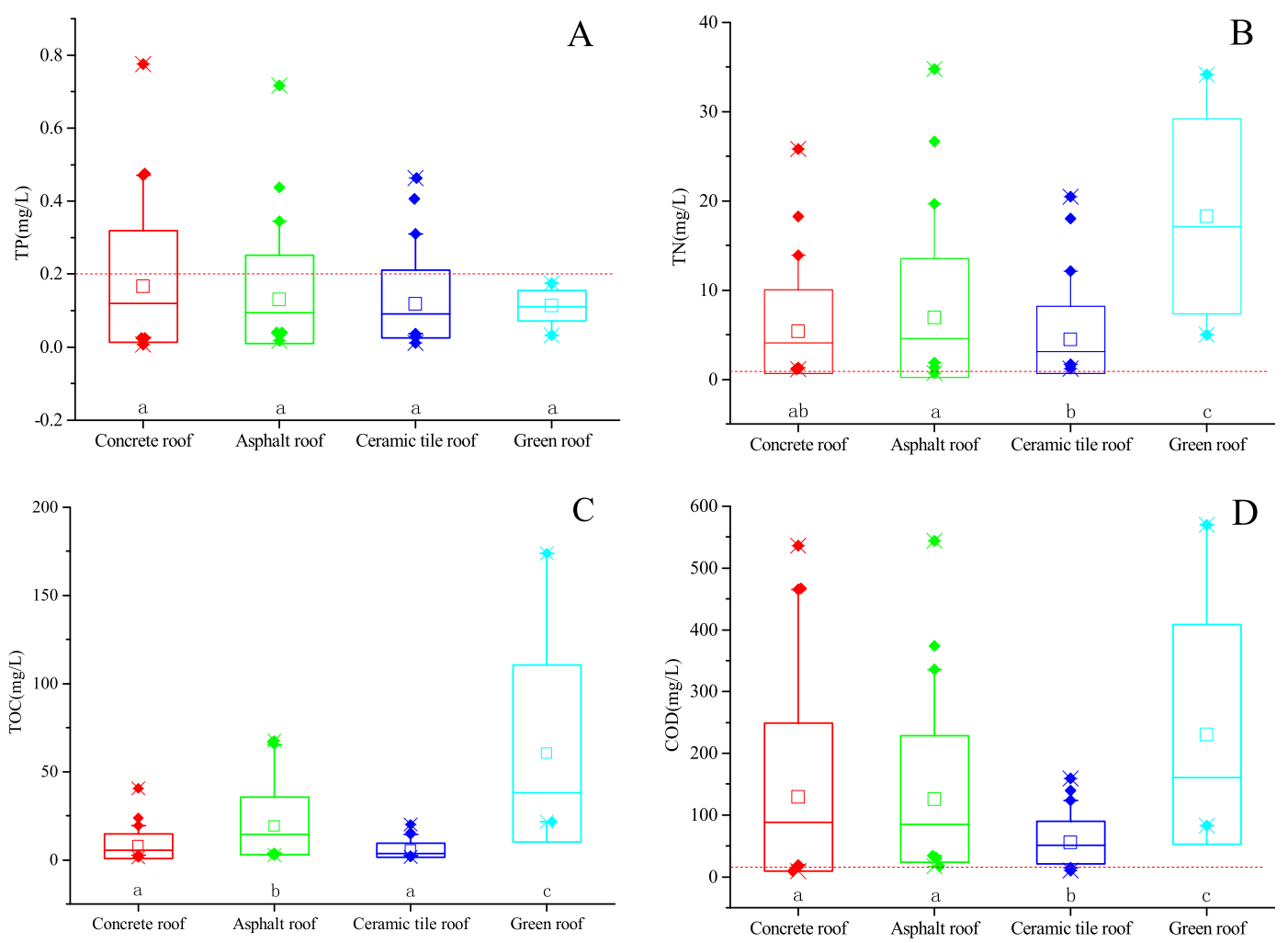

Fig. 5. Box plot diagram of the (A) TP, (B) TN, (C) TOC and (D) COD values of rainwater harvested from the four roofing materials. See the legend in Fig. 4.
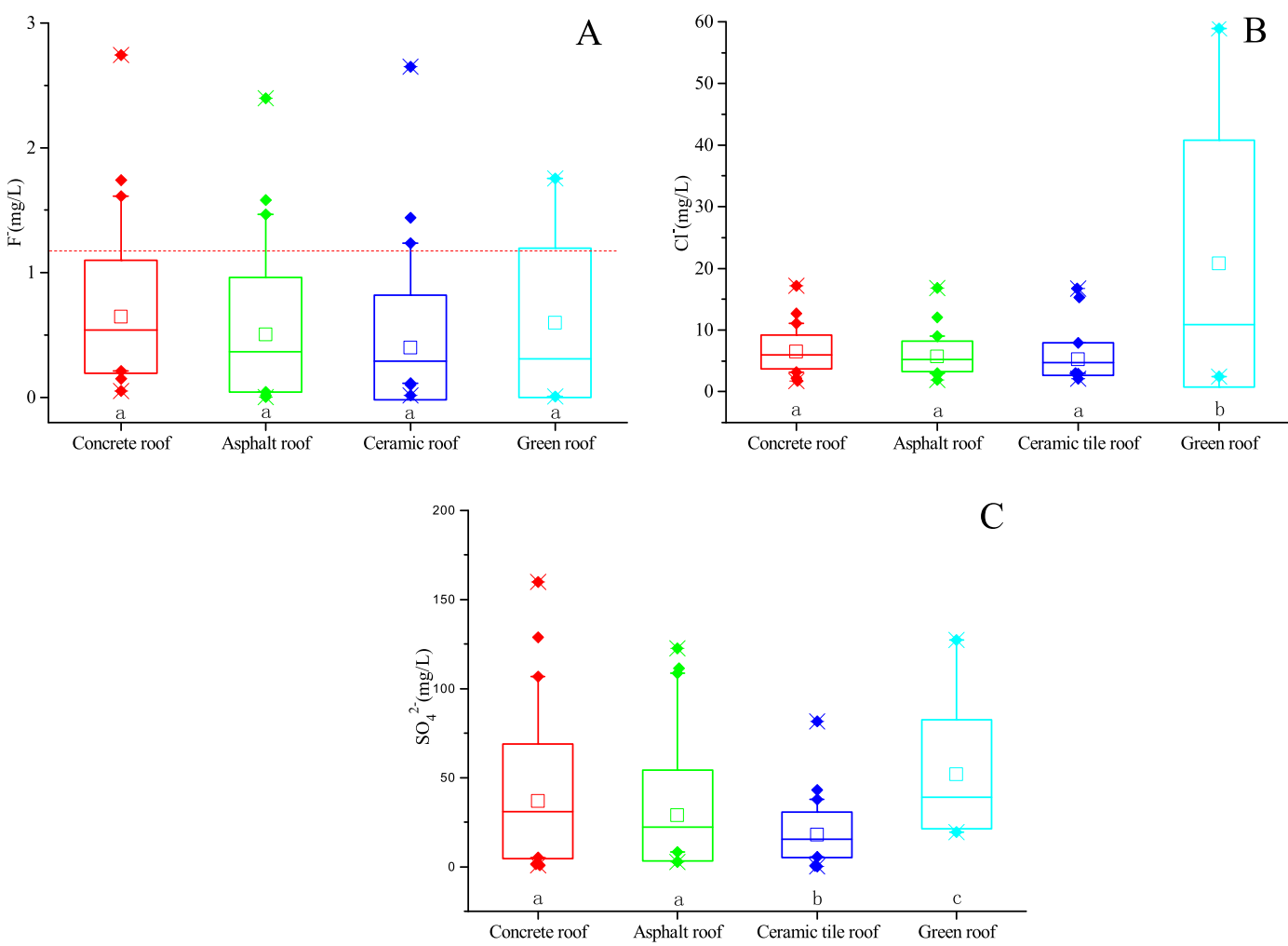

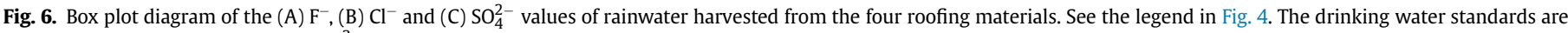
$250 \mathrm{mg} / \mathrm{L}$ for $\mathrm{Cl}^{-}$and $250 \mathrm{mg} / \mathrm{L}$ for $\mathrm{SO}_{4}^{2-}$, respectively. 

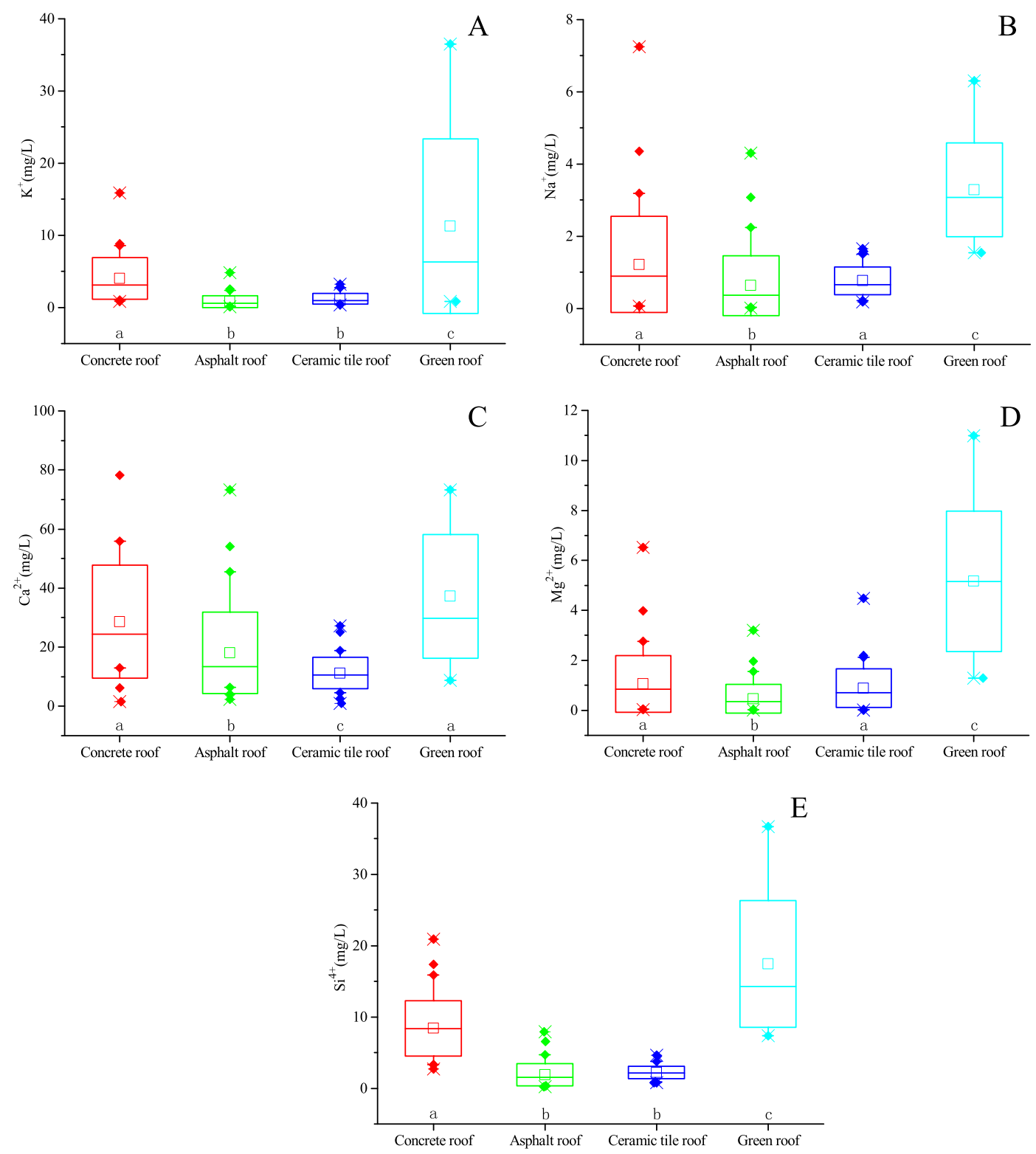

Fig. 7. Box plot diagram of the (A) $\mathrm{K}^{+}$, (B) $\mathrm{Na}^{+}$, (C) $\mathrm{Ca}^{2+}$, (D) $\mathrm{Mg}^{2+}$ and (E) $\mathrm{Si}^{4+}$ values of rainwater harvested from the four roofing materials. See the legend in Fig. 4 .
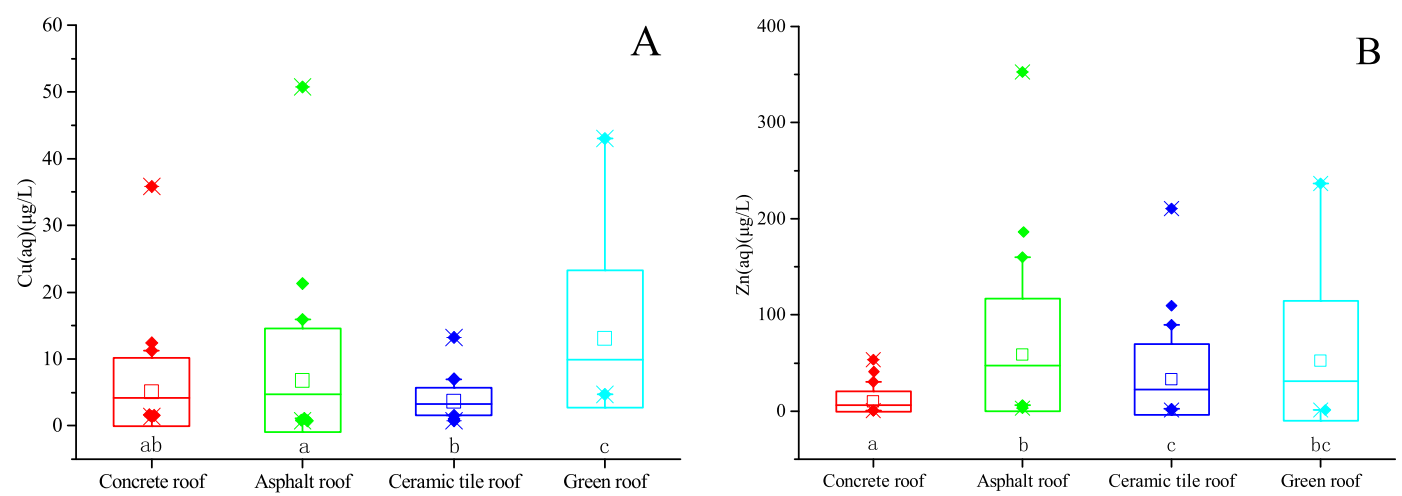

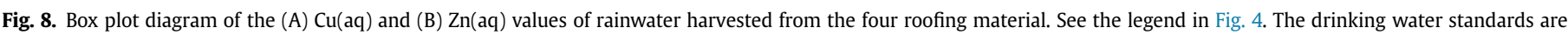
$1000 \mu \mathrm{g} / \mathrm{L}$ for $\mathrm{Cu}(\mathrm{aq})$ and $1000 \mu \mathrm{g} / \mathrm{L}$ for $\mathrm{Zn}(\mathrm{aq})$, respectively. 
Table 1

The seasonal variations of water quality from the concrete, asphalt and ceramic tile roofs.

\begin{tabular}{|c|c|c|c|c|c|c|}
\hline \multirow[t]{2}{*}{ Parameter } & \multicolumn{2}{|l|}{ Concrete roof } & \multicolumn{2}{|l|}{ Asphalt roof } & \multicolumn{2}{|l|}{ Ceramic tile roof } \\
\hline & Order & $P$ & Order & $P$ & Order & $P$ \\
\hline $\mathrm{pH}$ & $\mathrm{Su}>\mathrm{Sp}>\mathrm{A}>\mathrm{W}$ & 0.018 & $\mathrm{Su}>\mathrm{Sp}>\mathrm{A}>\mathrm{W}$ & 0.043 & $\mathrm{Su}>\mathrm{Sp}>\mathrm{A}>\mathrm{W}$ & 0.004 \\
\hline EC & $\mathrm{W}>\mathrm{Sp}>\mathrm{A}>\mathrm{Su}$ & 0.036 & $\mathrm{~W}>\mathrm{Sp}>\mathrm{A}>\mathrm{Su}$ & 0.526 & $\mathrm{~W}>\mathrm{Sp}>\mathrm{A}>\mathrm{Su}$ & 0.154 \\
\hline TSS & $\mathrm{Sp}>\mathrm{Su}>\mathrm{A}>\mathrm{W}$ & 0.038 & $\mathrm{Sp}>\mathrm{A}>\mathrm{Su}>\mathrm{W}$ & 0.044 & $\mathrm{~W}>\mathrm{A}>\mathrm{Sp}>\mathrm{Su}$ & 0.717 \\
\hline COD & $\mathrm{Sp}>\mathrm{W}>\mathrm{Su}>\mathrm{A}$ & 0.695 & $\mathrm{Sp}>\mathrm{Su}>\mathrm{W}>\mathrm{A}$ & 0.566 & $\mathrm{~W}>\mathrm{A}>\mathrm{Sp}>\mathrm{Su}$ & 0.095 \\
\hline TOC & $\mathrm{W}>\mathrm{Sp}>\mathrm{A}>\mathrm{Su}$ & 0.139 & $\mathrm{Su}>\mathrm{W}>\mathrm{Sp}>\mathrm{A}$ & 0.705 & $\mathrm{~W}>\mathrm{A}>\mathrm{Sp}>\mathrm{Su}$ & 0.035 \\
\hline TP & $\mathrm{Sp}>\mathrm{Su}>\mathrm{A}>\mathrm{W}$ & 0.029 & $\mathrm{Sp}>\mathrm{A}>\mathrm{Su}>\mathrm{W}$ & 0.038 & $\mathrm{~W}>\mathrm{Sp}>\mathrm{Su}>\mathrm{A}$ & 0.381 \\
\hline $\mathrm{TN}$ & $\mathrm{W}>\mathrm{Sp}>\mathrm{Su}>\mathrm{A}$ & 0.012 & $\mathrm{~W}>\mathrm{Sp}>\mathrm{A}>\mathrm{Su}$ & 0.013 & $\mathrm{~W}>\mathrm{Sp}>\mathrm{A}>\mathrm{Su}$ & 0.004 \\
\hline $\mathrm{K}^{+}$ & $\mathrm{W}>\mathrm{Sp}>\mathrm{A}>\mathrm{Su}$ & 0.028 & $\mathrm{~W}>\mathrm{Sp}>\mathrm{A}>\mathrm{Su}$ & 0.043 & $\mathrm{~W}>\mathrm{A}>\mathrm{Sp}>\mathrm{Su}$ & 0.046 \\
\hline $\mathrm{Na}^{+}$ & $\mathrm{W}>\mathrm{Sp}>\mathrm{A}>\mathrm{Su}$ & 0.006 & $\mathrm{~W}>\mathrm{Sp}>\mathrm{A}>\mathrm{Su}$ & 0.026 & $\mathrm{~W}>\mathrm{A}>\mathrm{Su}>\mathrm{Sp}$ & 0.021 \\
\hline $\mathrm{Ca}^{2+}$ & $\mathrm{W}>\mathrm{Sp}>\mathrm{A}>\mathrm{Su}$ & 0.045 & $\mathrm{~W}>\mathrm{Sp}>\mathrm{Su}>\mathrm{A}$ & 0.647 & $\mathrm{~W}>\mathrm{Sp}>\mathrm{Su}>\mathrm{A}$ & 0.569 \\
\hline $\mathrm{Mg}^{2+}$ & $\mathrm{W}>\mathrm{Sp}>\mathrm{A}>\mathrm{Su}$ & 0.000 & $\mathrm{Sp}>\mathrm{W}>\mathrm{A}>\mathrm{Su}$ & 0.001 & $\mathrm{~W}>\mathrm{Sp}>\mathrm{A}>\mathrm{Su}$ & 0.027 \\
\hline $\mathrm{Si}^{4+}$ & $\mathrm{W}>\mathrm{Sp}>\mathrm{A}>\mathrm{Su}$ & 0.474 & $\mathrm{Su}>\mathrm{Sp}>\mathrm{A}>\mathrm{W}$ & 0.021 & $\mathrm{Su}>\mathrm{Sp}>\mathrm{A}>\mathrm{W}$ & 0.542 \\
\hline $\mathrm{F}^{-}$ & $\mathrm{A}>\mathrm{W}>\mathrm{Sp}>\mathrm{Su}$ & 0.049 & $\mathrm{~W}>\mathrm{A}>\mathrm{Sp}>\mathrm{Su}$ & 0.286 & $\mathrm{~A}>\mathrm{W}>\mathrm{Sp}>\mathrm{Su}$ & 0.214 \\
\hline $\mathrm{Cl}^{-}$ & $\mathrm{W}>\mathrm{Sp}>\mathrm{Su}>\mathrm{A}$ & 0.488 & $\mathrm{~W}>\mathrm{Sp}>\mathrm{A}>\mathrm{Su}$ & 0.313 & $\mathrm{~A}>\mathrm{Sp}>\mathrm{W}>\mathrm{Su}$ & 0.176 \\
\hline $\mathrm{SO}_{4}^{2-}$ & $\mathrm{W}>\mathrm{Sp}>\mathrm{A}>\mathrm{Su}$ & 0.146 & $\mathrm{~W}>\mathrm{Sp}>\mathrm{A}>\mathrm{Su}$ & 0.286 & $\mathrm{~W}>\mathrm{Sp}>\mathrm{A}>\mathrm{Su}$ & 0.009 \\
\hline $\mathrm{DCu}$ & $\mathrm{Sp}>\mathrm{W}>\mathrm{Su}>\mathrm{A}$ & 0.092 & $\mathrm{Sp}>\mathrm{Su}>\mathrm{W}>\mathrm{A}$ & 0.025 & $\mathrm{~W}>\mathrm{Sp}>\mathrm{A}>\mathrm{Su}$ & 0.530 \\
\hline DZn & $\mathrm{W}>\mathrm{Sp}>\mathrm{A}>\mathrm{Su}$ & 0.027 & $\mathrm{Sp}>\mathrm{W}>\mathrm{A}>\mathrm{Su}$ & 0.004 & $\mathrm{~W}>\mathrm{Sp}>\mathrm{A}>\mathrm{Su}$ & 0.004 \\
\hline
\end{tabular}

Note: $\mathrm{Sp}=$ Spring; $\mathrm{Su}=$ Summer; $\mathrm{A}=$ Autumn; $\mathrm{W}=$ Winter. $P$ is the significant level of the different tested by nonparametric Kruskall-Wallis test.

ceramic tile roofs, and the lowest TN concentration in autumn was from the concrete roof.

The seasonal pattern of pollutant concentrations varied between pollutants and roofing material. On the concrete roof, the highest TSS and TP values were detected in spring and the highest $\mathrm{EC}, \mathrm{K}^{+}, \mathrm{Na}^{+}, \mathrm{Ca}^{2+}, \mathrm{Mg}^{2+}$, and $\mathrm{Zn}(\mathrm{aq})$ concentrations in winter. On the asphalt roof, the highest TSS, TP, $\mathrm{Mg}^{2+}, \mathrm{Cu}(\mathrm{aq})$ and $\mathrm{Zn}(\mathrm{aq})$ values were detected in spring and the highest $\mathrm{K}^{+}$and $\mathrm{Na}^{+}$concentrations in winter. On the ceramic tile roof, the TOC, TP and $\mathrm{Zn}(\mathrm{aq})$ values detected in winter were significantly higher than for the other seasons.

\subsection{Effect of rainfall characteristics on runoff water quality for conventional roofs}

Correlation analyses between the water quality parameters and rainfall characteristics (Table 2 ) show very significant negative correlation $(P<0.01)$ between rainfall volume and the following parameters: EC, COD, TP, TN, $\mathrm{K}^{+}, \mathrm{Na}^{+}, \mathrm{Ca}^{2+}, \mathrm{Mg}^{2+}, \mathrm{F}^{-}$, $\mathrm{Cl}^{-}, \mathrm{SO}_{4}^{2-}, \mathrm{TOC}, \mathrm{Cu}(\mathrm{aq})$ and $\mathrm{Zn}(\mathrm{aq})$. There is a significant negative correlation $(P<0.05)$ between rainfall volume and $\mathrm{Si}^{4+}$. The highest significant correlation is found between rainfall and TOC, $\mathrm{EC}$ and $\mathrm{F}^{-}$.

The ADWP markedly affected the quality of runoff water, with the exception of $\mathrm{pH}, \mathrm{Na}^{+}$and $\mathrm{F}^{-}$. There is a very significant positive correlation $(P<0.01)$ between the length of the ADWP and the following parameters: EC, COD, TP, TN, TSS, $\mathrm{Ca}^{2+}, \mathrm{Mg}^{2+}, \mathrm{Si}^{4+}, \mathrm{Cl}^{-}$, $\mathrm{SO}_{4}^{2-}$, TOC and $\mathrm{Cu}(\mathrm{aq})$. There is a significant positive correlation $(P<0.05)$ between the length of the ADWP and the following parameters: $\mathrm{K}^{+}$and $\mathrm{Zn}(\mathrm{aq})$.

Last rainfall volume (LRV: the volume of rainfall in the last event preceding the ADWP) markedly affected the quality of runoff water from the roofs, with the exception of $\mathrm{pH}, \mathrm{TSS}, \mathrm{K}^{+}, \mathrm{Ca}^{2+}, \mathrm{Mg}^{2+}, \mathrm{Si}^{4+}$, $\mathrm{Cu}(\mathrm{aq})$ and $\mathrm{Zn}(\mathrm{aq})$. There is a very significant negative correlation $(P<0.01)$ between the LRV and the following parameters: EC, COD, $\mathrm{TP}, \mathrm{TN}, \mathrm{Na}^{+}$and $\mathrm{F}^{-}$. The correlation between the $\mathrm{LRV}$ and $\mathrm{Cl}^{-}, \mathrm{SO}_{4}^{2-}$ and TOC is negative and significant $(P<0.05)$.

The maximum rainfall intensity (MRI) showed a significant negative correlation $(P<0.01)$ with the following parameters: $\mathrm{EC}$, $\mathrm{TN}, \mathrm{K}^{+}, \mathrm{Na}^{+}, \mathrm{Ca}^{2+}, \mathrm{Mg}^{2+}, \mathrm{Si}^{4+}, \mathrm{F}^{-}, \mathrm{Cl}^{-}, \mathrm{SO}_{4}^{2-}, \mathrm{TOC}, \mathrm{Cu}(\mathrm{aq})$ and $\mathrm{Zn}(\mathrm{aq})$. There is also a significant negative correlation $(P<0.05)$ between the MRI and TSS.

\section{Discussion}

Compared to road runoff, roof runoff is relatively clean, because the roof areas are rarely affected by human activities. The main factors affecting roof runoff quality include the following three aspects: 1) roof characteristics (e.g., type, age, roughness). The compounds contained in roofing materials can leach into the runoff (Chang et al., 2004) and older roofs contain large amounts of suspended solids; 2) rainfall characteristics (e.g., precipitation, rainfall intensity, ADWP); 3) Environment characteristics (e.g., seasonal variation, atmospheric pollution, roof surrounding environment). In general, roof temperatures are much higher than temperatures of other surfaces due to lower albedo and reduced shading effects from surrounding trees, which increases the rates of chemical reactions and organic decomposition of materials that have accumulated on rooftops (Chang and Crowley, 1993). In addition, the leaves, dead insects, and bird waste, added to roofs by interception and deposition affect the water quality of the roof runoff (Chang et al., 2004).

Table 2

Spearman correlation coefficients between the water quality parameters and rainfall characteristics for the conventional (concrete, asphalt and tile roofs) set of roofs.

\begin{tabular}{lllll}
\hline Parameters & RV & ADWP & LRV & MRI \\
\hline $\mathrm{pH}$ & 0.149 & 0.051 & 0.064 & 0.037 \\
$\mathrm{EC}$ & $-0.650^{* *}$ & $0.328^{* *}$ & $-0.227^{* *}$ & $-0.538^{* *}$ \\
$\mathrm{COD}$ & $-0.288^{* *}$ & $0.239^{* *}$ & $-0.242^{* *}$ & -0.102 \\
$\mathrm{TP}$ & $-0.216^{* *}$ & $0.406^{* *}$ & $-0.224^{* *}$ & -0.014 \\
$\mathrm{TN}$ & $-0.477^{* *}$ & $0.396^{* *}$ & $-0.222^{* *}$ & $-0.338^{* *}$ \\
$\mathrm{TSS}$ & -0.041 & $0.267^{* *}$ & -0.155 & $0.196^{*}$ \\
$\mathrm{~K}^{+}$ & $-0.435^{* *}$ & $0.197^{*}$ & -0.177 & $-0.327^{* *}$ \\
$\mathrm{Na}^{+}$ & $-0.650^{* *}$ & 0.103 & $-0.322^{* *}$ & $-0.491^{* *}$ \\
$\mathrm{Ca}^{2+}$ & $-0.441^{* *}$ & $0.426^{* *}$ & -0.142 & $-0.424^{* *}$ \\
$\mathrm{Mg}^{2+}$ & $-0.424^{* *}$ & $0.232^{* *}$ & -0.152 & $-0.371^{* *}$ \\
$\mathrm{Si}^{4+}$ & $-0.212^{*}$ & $0.244^{* *}$ & 0.017 & $-0.239^{* *}$ \\
$\mathrm{~F}^{-}$ & $-0.603^{* *}$ & 0.137 & $-0.308^{* *}$ & $-0.485^{* *}$ \\
$\mathrm{Cl}^{-}$ & $-0.387^{* *}$ & $0.406^{* *}$ & $-0.215^{*}$ & $-0.396^{* *}$ \\
$\mathrm{SO}_{4}^{2-}$ & $-0.534^{* *}$ & $0.222^{* *}$ & $-0.203^{*}$ & $-0.458^{* *}$ \\
$\mathrm{TOC}_{\mathrm{DCu}}$ & $-0.570^{* *}$ & $0.267^{* *}$ & $-0.210^{*}$ & $-0.456^{* *}$ \\
$\mathrm{DZn}^{*}$ & $-0.422^{* *}$ & $0.395^{* *}$ & -0.065 & $-0.399^{* *}$ \\
\hline & $-0.368^{* *}$ & $0.193^{*}$ & -0.06 & $-0.264^{* *}$ \\
\hline
\end{tabular}

Note: ${ }^{*} P<0.05$; ${ }^{* *} P<0.01$. RV $=$ Rainfall volume; ADWP $=$ Antecedent dry weather period; LRV = Last rainfall volume, the volume of rainfall in the last event preceding the antecedent dry period; MRI = Maximum rainfall intensity. 


\subsection{Effect of different roofing materials on harvested rainwater quality}

The green roof assembly consisted of four layers, namely a vegetation layer (substrate layer), a filter layer, a drainage layer and a waterproof layer (Fig. 3). It is worth noting that the selected substrate was a commercial product manufactured using a mixture of lightweight materials (the volume ratio of each matrix: peat soil:vermiculite:perlite:sawdust was 4:3:2:1). The selection of nutritive soil is often used in horticultural cultivation in China. Peat soil contains a large amount of organic matter (57-60\%), nutrients TN (2\%), TP (0.06\%), total potassium (0.6\%) and trace elements (e.g., calcium, magnesium, copper, zinc) (Yuan et al., 2005). The vermiculite contains large amount of trace elements (e.g., calcium, magnesium, iron, aluminum, silicon). The main ingredients of perlite are silicon dioxide (70\%) and water (3-5\%) (Yu et al., 2001). In addition, the sawdust also contains lots of nitrogen, phosphorous and potassium. On the green roof, the mean concentrations of EC, $\mathrm{TN}, \mathrm{COD}, \mathrm{TOC}, \mathrm{Cl}^{-}, \mathrm{SO}_{4}^{2-}, \mathrm{K}^{+}, \mathrm{Na}^{+}, \mathrm{Mg}^{2+}, \mathrm{Si}^{4+}$ and $\mathrm{Cu}(\mathrm{aq})$ were significantly higher than those from the other roofs, mainly because the substrate layer contains many organic substances, nutrients and trace elements. Vijayaraghavan et al. (2012) and Berndtsson et al. (2009) reported that green roofs act as a source of ions. Moran et al. (2005) observed the substantial release of TN from green roofs. Bliss et al. (2009) showed the COD of green roof water samples was greater than those from a control roof (conventional ballasted membrane roof), and Mason et al. (1999) found that the roof runoff infiltration through soil showed that a major part of DOC behaved conservatively during infiltration. Therefore, the green roof was not suitable for rainwater harvesting applications.

Typically, concrete is composed of cement, sand and gravel (cement:gravel:sand $=1: 1.5: 3$ ). The cement is composed of limestone, clay and slag (iron), and contains lots of alkaline substances, such as calcium carbonate $\left(\mathrm{CaCO}_{3}\right)$, silicon dioxide $\left(\mathrm{SiO}_{2}\right)$, aluminum oxide $\left(\mathrm{Al}_{2} \mathrm{O}_{3}\right)$, and iron oxide $\left(\mathrm{Fe}_{2} \mathrm{O}_{3}\right)$ (Wang et al., 2007). The sand is composed of minerals and tiny pieces of rock, and its main ingredient is silicon dioxide $\left(\mathrm{SiO}_{2}\right)$. The main ingredient of the gravel is also silicon dioxide $\left(\mathrm{SiO}_{2}\right)$; in addition, it contains some metal and nonmetal compounds. In conclusion, the concrete roof contains lots of alkaline substances and metals. Therefore, the mean $\mathrm{pH}$ of the concrete roof was significantly higher than the other roofs, mainly because of the alkaline nature of the concrete, which is consistent with other studies (Mendez et al., 2011). On the concrete roof, the mean concentration of TSS was significantly higher than the other roofing material samples. One explanation for this effect is that the concrete roof was easier to weather and age than the other roofs, which was supported by the amount of roof debris found on the concrete roof. Lee et al. (2012) reported that the mean concentration of TSS of the concrete tile $(309 \mathrm{mg} / \mathrm{L})$ and galvanized steel $(285.8 \mathrm{mg} / \mathrm{L})$ samples were significantly higher than the wooden shingle tiles and clay tiles. In addition, the concrete roof contained large concentrations of metals and cations, such as $\mathrm{Al}, \mathrm{Fe}, \mathrm{Ca}^{2+}$ and $\mathrm{Si}^{4+}$. Therefore, the mean concentrations of $\mathrm{K}^{+}, \mathrm{Ca}^{2+}$ and $\mathrm{Si}^{4+}$ from the concrete roof were significantly higher than those of asphalt and ceramic tile roofs.

Asphalt is a product of the processing of crude oil. The main elements contained in the asphalt are carbon and hydrogen, as well as small amounts of sulfur, nitrogen and oxygen (Lai, 2004). There are more than 50 kinds of trace elements contained in the processed asphalt from the crude oil, such as iron, nickel, vanadium, aluminum, copper and zinc. In conclusion, the asphalt roof contains numerous lots of organic pollutants, sulfur, nitrogen and metals. In our study, the mean concentrations of TOC and $\mathrm{Zn}$ (aq) from the asphalt roof were significantly higher than the concrete and ceramic tile roofs, and the mean concentrations of TN, COD and
$\mathrm{Cu}(\mathrm{aq})$ were higher than the concrete and ceramic tile roofs. Mendez et al. (2011) found that the asphalt fiberglass shingle roof was expected to be a source of organic matter. Drapper et al. (2000) found that TOC and COD concentrations in asphalt road runoff were 3-5 times higher than those from a concrete road.

The ceramic tiles are composed of Kaolin, clay, porcelain clay and lime glaze, their main constituents are silicon dioxide $\left(\mathrm{SiO}_{2}\right)$, aluminum oxide $\left(\mathrm{Al}_{2} \mathrm{O}_{3}\right)$ and water of crystallization (STSBC, 1996). They also contain small amounts of alkali metals and alkaline earth metals. On the ceramic tile roof, the mean concentrations of most of the water quality parameters were lower than the other roofs. One explanation for this effect is that the ceramic tile roof did not contain organic pollutants and nutrients. It was also more resistant to weathering and aging than the other roofs. Therefore, the ceramic tile roof was found to be the most suitable for rainwater harvesting applications.

\subsection{Effect of season on harvested rainwater quality}

The seasonal trends in water quality parameters have implications for the treatment and utilization of roof runoff. In our study, the mean concentration of most of the water quality parameters in summer and autumn was lower than those in winter and spring, mainly because most rainfall events in Chongqing occur during the summer and autumn. Therefore, the rainwater dilution of pollutants in the atmosphere and on the roof was greater in summer and autumn. Farreny et al. (2011) found that the higher the rainfall volume, the smaller the pollution load in the samples. Thus, the water quality of roof runoff in the rainy season (i.e., summer and autumn in this study) would be cleaner than that in winter and spring. Therefore, it is beneficial to harvest and utilize rainwater in summer and autumn in this region, and the non-point pollution control should be focused more on the treatment of roof runoff in spring and winter.

\subsection{Effect of rainfall characteristics on roof runoff water quality}

Attributes such as storm volume, rainfall intensity and AWDP may have various implications on the quality of runoff waters from roof surfaces. Generally, the higher the rainfall volume, the smaller the pollution load in the samples (Farreny et al., 2011). In our study, most of the water parameters have a significant negative correlation $(P<0.01)$ with rainfall volume. These results are similar to those found in a previous study by Kim et al. (2007) which found that the wide distribution of event mean concentrations (EMCs) is dependent on the total rainfall due to the dilution effect during a storm.

The dry period preceding a runoff event is the time during which pollutants accumulate on the roof surface. The cumulative amount of roof pollution is influenced by the type of roof and ambient conditions contributing to the removal of sediments, such as wind, temperature, solar radiation and relative humidity. In our study, there is a significant positive correlation $(P<0.01)$ between the ADWP and most parameters. These results are consistent with those obtained by Fewtrell and Kay (2007) who observed that ADWP can markedly affect the quality of runoff water. Kayhanian et al. (2003) used multiple linear regression analysis on data collected in California to find a statistically significant effect of ADWP on runoff concentrations for 25 of the 33 constituents tested. Twenty-three of the significant regressions had a positive coefficient (i.e., concentrations increase with longer ADWPs) with only two ( $\mathrm{pH}$ and diazinon) showing a negative value.

Storm intensity may have a marked impact on the type and quantity of pollutants in runoff. It has been observed previously that there was a positive correlation between certain pollutant 
loads or concentrations and storm intensity measures (from highways) (Crabtree et al., 2008). In our study, the MRI showed a significant $(P<0.01)$ negative correlation with most parameters. These results are consistent with those obtained by Crabtree et al. (2006), who found a negative correlation between water quality parameters and storm intensity.

\subsection{Implications for rainfall harvesting}

To ensure the future water security in urban areas that experience urban stream depletion and water shortages due to global climate change and urban population growth, more clear water is demanded. Effective rainwater harvesting strategies are essential to meet the escalating demand for good quality water in sufficient quantities. An important advantage of rainwater harvesting is the ability to provide water at or near the point of consumption, reducing the operation and running costs. In addition, rainwater harvesting has fewer negative environmental impacts compared to other water supply technologies. Based on our results, the water quality of the roof runoff was closely related to the roofing material and the season when rainwater is harvested. Therefore, it is important when harvesting rainwater to choose the most suitable roofing material and season. In addition, we found that the main pollutants of roof runoff from the four roofs studied, which exceeded the drinking water standard, were TN and COD. For these reasons, it is better for the harvested rainwater to be used for non-potable and non-contacting purposes, such as toilet flushing, car washing and landscape irrigation.

\section{Conclusion}

Three types of conventional roofing material (concrete, asphalt and ceramic tiles), widely used in China, and one alternative roofing material (green) were examined for their suitability to harvest rainwater for domestic use. The $\mathrm{pH}, \mathrm{EC}, \mathrm{DO}, \mathrm{COD}, \mathrm{TP}, \mathrm{TN}, \mathrm{TOC}, \mathrm{TSS}$, $\mathrm{K}^{+}, \mathrm{Na}^{+}, \mathrm{Ca}^{2+}, \mathrm{Mg}^{2+}, \mathrm{Si}^{4+}, \mathrm{F}^{-}, \mathrm{Cl}^{-}, \mathrm{SO}_{4}^{2-}, \mathrm{Cu}(\mathrm{aq})$ and $\mathrm{Zn}(\mathrm{aq})$ were measured in the harvested rainwater and the following conclusions were drawn.

After comparison of the harvested rainwater from the four roofs, the ceramic tile roof was found to be the most suitable for rainwater harvesting applications due to it having the lowest mean concentration of the measured water quality parameters. However, the mean value of TN and COD from the ceramic tile roof exceeded the drinking water standards of 1.0 and $20 \mathrm{mg} / \mathrm{L}$, respectively. Therefore, rainwater harvested from roofs would require treatment prior to consumption.

With regard to the physical and chemical parameters, this study showed that the type of roofing material used has an influence on the quality of harvested rainwater. The $\mathrm{pH}$ and TSS of the samples from the concrete roof were significantly higher than those from the other roofs. The EC, TN, TOC, $\mathrm{COD}, \mathrm{Cl}^{-}, \mathrm{SO}_{4}^{2-}, \mathrm{K}^{+}, \mathrm{Na}^{+}, \mathrm{Mg}^{2+}, \mathrm{Si}^{4+}$ and $\mathrm{Cu}(\mathrm{aq})$ of the samples from the green roof were significantly higher than those from the other roofs, however, the mean value of $\mathrm{TP}$ and $\mathrm{pH}$ was lower. The seasonal trends in water quality parameters showed that the pollutant outputs in summer and autumn were lower than those in winter and spring. Therefore, the rainy seasons (i.e., summer and autumn in this study) are the more suitable ones for rainwater harvesting.

Analyses between the water quality parameters and rainfall characteristics revealed a higher correlation. There was a significant negative correlation $(P<0.01)$ between rainfall volume, MRI and most other parameters. There was a significant positive correlation $(P<0.01)$ between ADWP and most other parameters.

In conclusion, harvested rainwater quality was significantly affected by the roofing materials. Therefore, harvested rainwater requires careful analysis to determine the effects of these materials on water quality. In our study, the influence of microbial pathogens and pesticides was not examined and the first flush effect was not investigated. Therefore, further study is necessary to consider these parameters and the first flush effect.

\section{Acknowledgments}

The study was funded by the National Water Pollution Control and Management Technology Major Projects of China (No. 2012ZX07307) and the National Natural Science Foundation of China (No. 41030744 and No. 40901265).

\section{Appendix A. Supplementary material}

Supplementary data related to this article can be found online at http://dx.doi.org/10.1016/j.jenvman.2013.11.009.

\section{References}

Ahmed, W., Huygens, F., Goonetilleke, A., Gardner, T., 2008. Real-time PCR detection of pathogenic microorganisms in roof-harvested rainwater in Southeast Queensland, Australia. Appl. Environ. Microbiol. 74 (17), 5490-5496.

Berndtsson, J.C., Bengtsson, L., Jinno, K., 2009. Runoff water quality from intensive and extensive vegetated roofs. Ecol. Eng. 35 (3), 369-380.

Bliss, D.J., Neufeld, R.D., Ries, R.J., 2009. Storm water runoff mitigation using a green roof. Environ. Eng. Sci. 26 (2), 407-418.

Chang, M., Crowley, C.M., 1993. Preliminary observations on water quality of storm runoff from four selected residential roofs. J. Am. Water Resour. Assoc. 29 (5), 777-783.

Chang, M., McBroom, M.W., Scott Beasley, R., 2004. Roofing as a source of nonpoint water pollution. J. Environ. Manage. 73 (4), 307-315.

Crabtree, B., Dempsey, P., Johnson, I., Whitehead, M., 2008. The development of a risk-based approach to managing the ecological impact of pollutants in highway runoff. Water Sci. Technol. 57 (10), 1595-1600.

Crabtree, B., Moy, F., Whitehead, M., Roe, A., 2006. Monitoring pollutants in highway runoff. Water Environ. J. 20 (4), 287-294.

Despins, C., Farahbakhsh, K., Leidl, C., 2009. Assessment of rainwater quality from rainwater harvesting systems in Ontario, Canada. Aqua 58 (2), 117-134.

Drapper, D., Tomlinson, R., Williams, P., 2000. Pollutant concentrations in road runoff: Southeast Queensland case study. J. Environ. Eng. 126 (4), 313-320.

Farreny, R., Morales-Pinzón, T., Guisasola, A., Tayà, C., Rieradevall, J., Gabarrell, X., 2011. Roof selection for rainwater harvesting: quantity and quality assessments in Spain. Water Res. 45 (10), 3245-3254.

Fewtrell, L., Kay, D., 2007. Microbial quality of rainwater supplies in developed countries: a review. Urban Water J. 4 (4), 253-260.

Fletcher, T.D., Deletic, A., Mitchell, V.G., Hatt, B.E., 2008. Reuse of urban runoff in Australia: a review of recent advances and remaining challenges. J. Environ. Qual. 37 (5 Suppl.), S-116-S-127.

Förster, J., 1999. Variability of roof runoff quality. Water Sci. Technol. 39 (5), 137-144.

Gonçalves, F., Andrade, M., Forti, M., Astolfo, R., Ramos, M., Massambani, O., Melfi, A., 2003. Preliminary estimation of the rainfall chemical composition evaluated through the scavenging modeling for North-Eastern Amazonian region (Amapá State, Brazil). Environ. Pollut. 121 (1), 63-73.

Huang, J.L., Du, P.F., Ou, Z.D., Li, M.X., Zhao, D.Q., He, W.Q., Wang, Z.S., 2006. Preliminary investigation on characterization of urban roof runoff in Macau. Acta Sci. Circumst. 26 (7), 1076-1081.

Kayhanian, M., Singh, A., Suverkropp, C., Borroum, S., 2003. Impact of annual average daily traffic on highway runoff pollutant concentrations. J. Environ. Eng. 129 (11), 975-990.

Kim, L.H., Ko, S.O., Jeong, S., Yoon, J., 2007. Characteristics of washed-off pollutants and dynamic EMCs in parking lots and bridges during a storm. Sci. Total Environ. 376 (1), 178-184

Lai, G.H., 2004. The effect of asphalt chemical composition of water damage on the road. China Foreign Highway 24 (4), 52-53.

Lee, J.Y., Bak, G., Han, M., 2012. Quality of roof-harvested rainwater - comparison of different roofing materials. Environ. Pollut. 162, 422-429.

Lee, J.Y., Yang, J.S., Han, M., Choi, J., 2010. Comparison of the microbiological and chemical characterization of harvested rainwater and reservoir water as alternative water resources. Sci. Total Environ. 408 (4), 896-905.

Lye, D.J., 2009. Rooftop runoff as a source of contamination: a review. Sci. Total Environ. 407 (21), 5429-5434.

Mason, Y., Ammann, A.A., Ulrich, A., Sigg, L., 1999. Behavior of heavy metals, nutrients, and major components during roof runoff infiltration. Environ. Sci. Technol. 33 (10), 1588-1597.

Mendez, C.B., Klenzendorf, J.B., Afshar, B.R., Simmons, M.T., Barrett, M.E., Kinney, K.A., Kirisits, M.J., 2011. The effect of roofing material on the quality of harvested rainwater. Water Res. 45 (5), 2049-2059.

Moran, A., Hunt, B., Smith, J., 2005. Hydrologic and water quality performance from greenroofs in Goldsboro and Raleigh, North Carolina. 4-6. 
Ren, Y.F., Wang, X.K., Ouyang, Z.Y., Zheng, H., Duan, X.N., Miao, H., 2008. Stormwater runoff quality from different surface in an urban catchment in Beijing, China. Water Environ. Res. 80 (8), 719-724.

Simmons, G., Hope, V., Lewis, G., Whitmore, J., Gao, W., 2001. Contamination of potable roof-collected rainwater in Auckland, New Zealand. Water Res. 35 (6), $1518-1524$.

State Environment Protection Agency of China (SEPAC), 2002a. Methods of Monitoring and Analysis for Water and Wastewater, fourth ed. China Environmental Science Press, Beijing. (in Chinese).

State Environment Protection Agency of China (SEPAC), 2002b. Environmental Quality Standards for Surface Water (GB3838-2002). China Environmenta Science Press, Beijing (in Chinese).

State Technical Supervision Bureau of China (STSBC), 1996. Methods of Chemical Analysis for Ceramic Materials and Articles (GB/T 4734-1996). Standards Press of China, Beijing (in Chinese).

Van Roon, M., 2007. Water localisation and reclamation: steps towards low impact urban design and development. J. Environ. Manage. 83 (4), 437-447.
Vialle, C., Sablayrolles, C., Lovera, M., Huau, M.-C., Jacob, S., MontréjaudVignoles, M., 2012. Water quality monitoring and hydraulic evaluation of a household roof runoff harvesting system in France. Water Resour. Manage. 26 (8), 2233-2241.

Vijayaraghavan, K., Joshi, U., Balasubramanian, R., 2012. A field study to evaluate runoff quality from green roofs. Water Res. 46 (4), 1337-1345.

Wang, B., Li, T., 2009. Buildup characteristics of roof pollutants in the Shanghai urban area, China. J. Zhejiang Univ. Sci. A 10 (9), 1374-1382.

Wang, L.J., Zheng, F.Y., Chi, Y.H., 2007. Theoretical and experimental studies on CCRM concrete. J. Dalian Univ. Technol. 47 (2), 222-227.

Yu, L.H., Ou, H., Yuan, Y.F., 2001. Study on perlite used as admixture in high performance concrete. Non-metallic Mines 24 (3), 24-26.

Yuan, J., Liu, F., Zhang, W.B., Luo, H.B., 2005. Growing status and evaluation of seedling stages of grass on fly ash. Chin. J. Ecol. 24 (5), 493-496.

Zobrist, J., Müller, S., Ammann, A., Bucheli, T., Mottier, V., Ochs, M., Schoenenberger, R., Eugster, J., Boller, M., 2000. Quality of roof runoff for groundwater infiltration. Water Res. 34 (5), 1455-1462. 